\title{
Smetana's Importance for the Development of Musical Life in Göteborg
}

\section{Anders Carlsson}

Göteborg at the time when Bedrich Smetana arrived was a small town on the outskirts of Central Europe, especially with regard to musical life and the standard of concerts. When Smetana arrived in 1856 the city had about 33000 inhabitants. At the end of the century the population was about 130000 , so there was a large increase during the period in population and trade and industry, as well as a flowering of cultural life.

During this period, musical life developed in an almost revolutionary way in Göteborg, at least if we study the structural development of public musical life. In fact, music-making shifted from one epoch to another. The most well-known fact from this period is that Bedřich Smetana stayed in Göteborg from 1856 until 1861, with a renewed stay in the spring of 1862. But there are also several other things that also deserve attention, namely that several attempts were made to create professional orchestras, long before attempts were made in Stockholm, the capital of Sweden. More about this in a moment.

Göteborg was founded in 1619 by king Gustavus Adolphus, and was built as a system of fortifications as protection against possible attacks from the west, especially from Denmark. Already from the beginning, rich merchants from other countries in Europe and their families were invited to settle in Göteborg, and this contributed to the establishment of a small but extremely rich class of merchants and their families, often coming from abroad.

This made Göteborg a very different city from Stockholm with its royal family and court, many nobles (West Sweden has never had many nobles), royal departments, the royal academy of music, royal conservatory, royal theatre and other institutions which give a massive façade of traditions, culture, refinement and good manners. These things are, of course, a guarantee for the continuous development of education, culture and refinement, but they can also be looked upon as a burden and a barrier to innovations and paradigm shifts. And this is the case when you compare the musical life of Göteborg with that of Stockholm. We find that a professional symphony orchestra was founded in Göteborg long before it was founded in Stockholm. Stockholm had an orchestra at the Royal 
Theatre, but this was not used as a symphony orchestra, a fact that many of the most prominent musicians and composers of the time complained about.

\section{Musical Life in Göteborg during the 1850s}

There is not only a complex relationship between the musical lives of Stockholm and Göteborg. There are also complex relationships within Göteborg's musical life itself. On the one hand, it can be described as progressive. But on the other hand, it can just as well be described as Smetana did when he wrote to Franz Liszt on April 10th, 1857:

Die Leute hier sind noch in einer antidiluvianischen Kunstanschauung fest eingerostet. Mozart ist ihr Abgott, aber noch nicht einmal verstanden, Beethoven wird gefürchtet, Mendelssohn als ungenießbar erklärt, und die neueren kennen sie nicht, Schumann's Werke habe ich zum Erstenmale hier vorgeführt. [...] Die Bewohner Göteborgs waren bis jetzt sich selbst überlassen, so daß sie gar nicht wußten, was in der Kunst vorgeht. Es sind meist sehr reiche Kaufleute, welche diese Kunst als sehr überflüssig nur in so weit trieben, um mich dieses Ausdrucks zu bedienen, als sie ihnen flüchtige Unterhaltung gewährte. ${ }^{1}$

Apart from Smetana there is also another man, one of Smetana's fellowcountrymen, who is of even greater importance for the development of musical life in Göteborg in the second half of the 19th century, at least if we look at it over a greater time-span: Joseph Czapek (1825-1915). Born in Prague, and after finishing his studies at the conservatory, he had been orchestra leader in Josef Gungl's orchestra. Czapek came to Göteborg in 1847 on a tour with the orchestra Steyermärkische Gesellschaft, in which he was also the orchestra leader. He settled permanently in the city and became immediately its most famous musician and one of the leading lights in the attempt to give shape to its musical life. Smetana and Czapek worked together and already in 1858, Neue Zeitschrift für Musik took note of the new development in Göteborg in an article about the city and especially of what Smetana and Czapek were doing there. ${ }^{2}$

But there is also a third factor that gave tremendous impetus to the development of musical life and the establishment of orchestras, namely the building of a new opera house (Nya Theatern - The New Theatre). The opera house was similar to the Semper opera house in Dresden. Smetana was still in his home country when it was inaugurated on September 15, 1859, and after his first visit

${ }^{1}$ Letter in Muzeum Bedřicha Smetany, NM-MBS, S 217/2077. See also Smetana in Briefen und Erinnerungen, hrsg. von František Bartoš (Prag: Artita, 1954), 52.

${ }^{2}$ Neue Zeitschrift für Musik, July 30, 1858, Vol. 49:5, pp. 54-55. 
to the opera house, on October 4, he wrote in his diary that it was quite impressive from outside, but all too small inside. At this time in Sweden no theatres outside of Stockholm had permanent ensembles with actors and singers. Instead, touring opera- and theatre companies visited different places and then required an orchestra. And this was the great importance for Göteborg's musical life, namely that the new opera house more or less made it necessary to also establish an orchestra, which at this time - 1859- was something that Joseph Czapek had especially strived to accomplish for some years.

These three factors stimulated the development of musical life in Göteborg: Smetana, Czapek, and the opera house. They all interacted. One can, of course, say that the first orchestra was not established until Smetana had gone home. He wrote to František Ulm in the spring of 1861 about how disappointed he was over all the discussions that had led to nothing (see further below). But at the same time, he was happy to hear about the new orchestra when it was started and thus wrote to his friend Isaac Philip Valentin in October 1862: "Sehr erfreut war ich zu hören, dass das Orchester gefiel. Vielleicht entsteht doch bald eine neue Phase im musikalischen Zustand Göteborgs...”3

\section{Smetana's Activities in Göteborg}

Smetana's main activity in Göteborg was teaching piano, mainly to the daughters of the bourgeois families. He also taught music theory and singing at his institute.

Another important activity involved leading the Harmoniska Sällskapet, (the Harmonic Society), an ordinary Musikverein, familiar to us from elsewhere during this time. With this society Smetana rehearsed every Monday evening and gave concerts regularly (for the members only), approximately three times a year with the choral works from the standard repertoire of Händel, Haydn, Mozart, Mendelssohn, and others.

As a third activity, he gave piano recitals and other concerts and also participated in others' concerts. According to Hana Séquardtová, he participated in 69 concerts/recitals altogether. ${ }^{4}$ Smetana himself organized some of these concerts, as, for example, the chamber concerts together with Joseph Czapek. In those Smetana played a major roll. But there were also a great number of concerts given by others, for example a singer who asked professional musicians and amateurs music-lovers - around him/her to join the concert. Smetana could thus in some concerts perform great works, a piano concerto or full piano sonata, and in others

\footnotetext{
${ }^{3}$ Valentinska familjearkivet [the Valentin family archives] L 112:2a, Kungliga biblioteket [the Royal Library], Stockholm, Sweden.

${ }^{4}$ Hana Séquardtová, Bedrich Smetana (Leipzig: Verlag Philipp Reclam jun., 1985), 64.
} 
perform only one movement from a piano sonata or accompany a singer. Or, to put it in other words: of the 69 concerts in total, some were of high artistic quality with Smetana as a prominent artist, and some were of considerably lower quality where Smetana played a not so prominent roll.

What is special about some of the concerts is the introduction in Göteborg of what we today call "classical concerts" where only a few works of art were performed, for example a full piano trio with all movements. This new kind of concert is something that Czapek had started to arrange in 1854 with a small orchestra performing classical symphonies. This was also the pattern for the subscribed chamber concerts that Smetana organized every year together with Czapek and a third person, August Meissner, on the cello.

As a fourth activity, he composed. His most notable works are the three symphonic poems Richard III, Wallensteins Lager and Hakon Jarl, and also some piano compositions.

Smetana also wrote two reviews of concerts in the local newspaper. ${ }^{5}$ The first review was about a concert where Czapek's Messe Solennelle was performed and where Smetana also participated as a bass-singer in the choir. In the article, Smetana discussed the opus very thoroughly. The second review was about a concert with the two singers Herman and Ida Cesar, and the reason why Smetana wrote the article was that he was astonished at their artistically high level. Smetana wrote that he expected to hear singers at the artistically low level that he was used to hearing, without grounding, method and so forth. As Smetana expressed himself with those words, he gave at the same time a judgment about the musical standard in Göteborg, even if it was indirectly.

Looking at these five activities, his main occupation was clearly as a piano teacher, choral leader, and concert pianist.

\section{The Musical Environment in Göteborg and the Prerequisites for Smetana's Work There}

In his letter to Franz Liszt in April 1857, as well as in many other letters and in his diary, he expressed his feelings or rather he mourned over his loneliness in Göteborg, especially in a cultural and musical sense. And of course this is true even if Smetana, as he often did, was expressing himself rather dramatically. But on the other hand, Göteborg was not completely lacking in musical resources. Apart from Joseph Czapek, there were some highly skilled and trained musicians, both men and women.

${ }^{5}$ Göteborgs Handels- och Sjöfarts Tidning December 16, 1858 and February 9, 1861. 
Music was an important ingredient in the drawing-room setting, and one of the fine arts cultivated by many members of the bourgeoisie. Some of the women had a professional career behind them before they were married, in some cases an international one, for instance Euphrosyne Abrahamson (née Leman). As married women they gave up their careers but often participated in concerts anonymously as "music lovers" and amateurs. Smetana noted in his diary his amazement at finding, at a soirée with Adelaide Leuhusen (née Valerius), that she sang with ease, passages from Lohengrin at sight. ${ }^{6}$

The men were more often instrumentalists, and went in for chamber music. Some of the wealthiest big merchants were competent instrumentalists, Arvid Ludvig Pineus for example, who sometimes participated in Smetana's and Czapek's chamber music recitals. Some of the families also had the scores to a great part of the classical repertoire, so that Smetana often began the planning of a chamber music recital by visiting his friend Mrs. Betty Magnusson to borrow some scores.

There was a tension in the interplay between the private and the public, and it also appears that musical life in the private sphere sometimes created impediments and paralysed the public. As an example, no one that did not belong to the finest circles of the upper class had access to the fine concerts/soirées of the Harmonic Society. The Harmonic Society had one of its own private soirées March 16, 1857, and performed Elijah by Mendelssohn, conducted by Smetana. As Smetana wrote in his diary the same evening: "Das Publikum bestand aus der Elite der Stadt, wurde von den Gesangsmitgliedern geladen." About a month later, April 18, 1857, Smetana gave a public concert with Joseph Czapek and some other musicians. As Smetana was to put the program of this concert together, he asked the Harmonic Society to join his and Czapek's concert by singing some parts of the same opus, Elijah. But to get the Harmonic Society to participate in Smetana's public concert was definitely not the same thing as to participate in a private soirée, and Smetana wrote that evening in his diary: "Viele der hiesigen Reichen haben die komische Idee, dass es sich nicht für sie schicke, im Conzert mitzuwirken.?!"

Another example of the tension between the private and public is the experience that Smetana sometimes had in connection with his chamber music recitals. After having been invited to various families in the days preceding the concert and having performed his program there, he was liable to find that only a small number came to listen on the day of the concert. Many listeners had already

\footnotetext{
${ }^{6}$ Smetana's diary February 5, 1859.

${ }^{7}$ Smetana's diary April 17, 1857.
} 
heard the program in a more comfortable setting without having to make their way to the public performance.

\section{The Conception of Smetana in Göteborg}

Gradually during the $19^{\text {th }}$ century a concept has grown about Smetana and Göteborg and it has continued to grow during the $20^{\text {th }}$ century. The concept was not founded by musicologists, but by journalists and other non-scholarly skilled writers, and sometimes it is based on narratives from people who met Smetana. Within this there is also a strong tendency of myth-making that has its genesis in a desire to foster the importance of Göteborg as a city that took care of the Czech composer in a period when he was otherwise abandoned. The concept consists of three parts:

\section{Smetana was of great importance for the musical life of Göteborg}

Smetana was indeed and in many ways of great importance for the development of the musical life in Göteborg. With his different activities he contributed to raising the level of musical taste and knowledge. On the other hand, not so many people realized how great he was, and there are witnesses for example from the English merchant families who looked upon him more as a funny little music teacher. Looking at the development of the musical life in Göteborg, it is also necessary to take Joseph Czapek into consideration. Czapek was in no way a musician at the same high artistic level as Smetana, but Czapek settled for good in Göteborg and had four to five decades of great activity as a musician, music teacher, band master, choral leader, composer, arranger, organizer, board-member of several musical and artistic societies, etc.

\section{Göteborg was of great importance for Smetana in his maturation to a great artist and composer. He always dreamed of coming back to Göteborg, and he was in close contact with his friends there.}

The importance of the Göteborg period for Smetana in his maturation as a great artist and composer is not easy to judge. From a Swedish standpoint it is important to cast light on the considerably lower level of musical life in Göteborg compared with Prague. To perform or even only to participate in 69 concerts during a five-year period sounds like a great activity, which it also was. But the quality of these concerts cannot in general terms be compared with the quality of the concerts given in the central parts of Europe at the same time. 
There are also some facts that cannot be ignored, such as Smetana's feelings about Göteborg, both at the beginning and at the end of his period in Göteborg, feelings that shifted and were both happy and sad, both with hope for the future and sadness of the time that had passed and that had led to nothing. In the letter quoted above to Franz Liszt he expressed his feelings of isolation, but he also expressed (although not quoted above) his hope for a future of activities and creativity. And after he had left Göteborg he wrote in his diary 11. 5.1861: "Die Episode meines Lebens - Göteborg vom Okt. 1856 bis Mai 1861 - ist also abgespielt, gehört der Vergangenheit, und ein neues Stadium öffnet sich mir. - Die Erinnerung an Vieles Schöne wird mir stets wach bleiben.”

According to Smetana's nephew Jan Rys, who stayed with the Smetana family in Göteborg, Smetana decided already before the end of the term in the spring of 1861 to leave Sweden for good. ${ }^{8}$ This was not only because of his own wishes but also due to continual pressure from his wife Bettina. In a diary from March 31, 1861 he wrote: “[...] aber ich kann mich in Gothenburg nicht vergraben. Ich muss versuchen, meine Werke endlich zu publizieren, und mir selbst Gelegenheit zu geben, für neues Schaffen Nahrung und frische Sporn zu erhalten.”

One of the last things Smetana did in Sweden was to go for a concert tour to Stockholm and Norrköping. In Stockholm he wrote a letter (March 25, 1861) to his friend in Prague the critic František Ulm and told him about the decision to leave Göteborg: "[...] wo ich eigentlich doch einen beschränkten Wirkungskreis hatte, und meine Wünsche in ächt Schwedischer Langsamkeit von Jahr zu Jahr verschoben - Gründung eines Orchesters - zu keinem Resultate geführt, [...]."

He also wrote about the lack of interest, slowness, conservatism, Philistinism, the mediocre musicians in Göteborg and so forth. ${ }^{9}$

The second part of the claim above, declares that Smetana wished to come back to Göteborg and that he stayed in close contact with his friends there. Smetana had, in the years to come, some contact with some of the friends in Göteborg, especially with the Valentin family but also with Mrs. Fröjda Benecke, later re-married as Mrs. Rubenson. The frequency of the writing was however not very high, and one important cause for the writing was that the young girl Charlotte Valentin stayed with the Smetana-family during 1863/64 for the purpose of studying piano. Another cause for the writing was the loans that Smetana received from Isaac Philip Valentin. A third cause was for the financial help that he received from some of the friends in Göteborg at the time when

\footnotetext{
${ }^{8}$ Josef Michl, "Vzpomínky Jana Rysa na Bedřicha Smetanu”, Hudební revue, vol. 5 (1912): 239.

${ }^{9}$ NM-MBS, S 217/456. See also Oldřich Pulkert, "Neznámé dopisy Bedřicha Smetany”, Hudebni rozbledy, no. 12 (1959): 137-140.
} 
he got his hearing problems. Apart from these writings there were also some further correspondence.

During the 1960s and 1970s, extensive research about Smetana was performed in Göteborg at the Museum of Theater History (Teaterhistoriska museet). The aim of the project was to find out as much as possible about Smetana and his stay in Göteborg. The project was conducted by the chief librarian Mr. Erik Hemlin, but in reality performed by two assistants, Mrs. Taimi Grehn and Mrs. Karin Rådmalm. The result of the project was documents of various kinds that were handed over to Prague, but there were also two articles written, one by Mrs. Taimi Grehn ${ }^{10}$ and one by Mr. Erik Hemlin. ${ }^{11}$ While the first-mentioned article is written with a deep knowledge founded in research, the latter article is more panegyric:

If Smetana, on the one hand, was of great importance for the development of a modern musical life in Göteborg, you can also say that the years in Göteborg were of enormous importance for Smetana's own growth as composer and leading personality in the field of culture. It was in the bright and free air of Göteborg and in the impact of all heartiness and friendship and the stimulating interest in him and his art that gave him strength and inspiration in his later activity as composer and creator of the Czech national opera.

This kind of gross generalization is not substantiated in research, and has, therefore, a more political character. In the position of representative for Sweden and the city of Göteborg, it was more important for the author to show brotherhood and to create tight bonds between the two countries: Czechoslovakia and Sweden. This is the function of representatives. On one hand it is understandable, but in the light of mythmaking it is more unfortunate. And in comparison with what Smetana himself wrote to František Ulm (quoted above), it is more or less false.

\section{Smetana once heard a very popular song "Ack Värmeland du sköna" and loved the tune so much that he more or less copied it for the Moldau theme.}

The third part of the Smetana concept is that Smetana found the Moldau theme in a popular song Ack Värmeland du sköna from a lyrical drama at that time:

${ }^{10}$ Taimi Grehn, “Om Bedrich Smetana och episoden Göteborg”, Göteborg Förr och Nu, vol. 5 (1968): 149-178.

${ }^{11}$ Erik Hemlin, Bedřich Smetana i Göteborg (Göteborg: Skrifter utgivna av Teaterhistoriska Samfundet i Göteborg, 1976). 


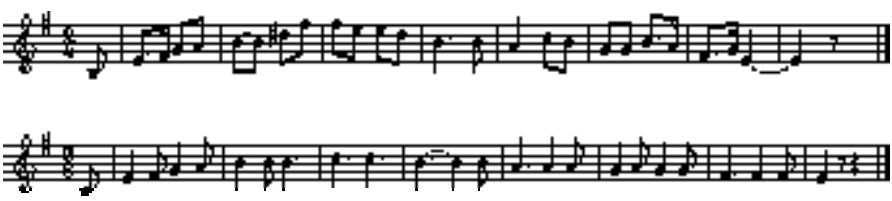

The themes from Ack Värmeland du sköna (above) and Moldau.

There are apparently similarities between the beginning of this tune and the Moldau theme, and therefore it fits very well with the concept that Smetana had a happy stay in Göteborg. People from Göteborg really love to know - as they think they do - that Sweden was of such great importance for Smetana that one of his most significantly characteristic themes, the Moldau theme, in fact is a greeting to Sweden. This part has become a true myth and also difficult to dispose of. The historian and author Arthur Koestler once visited Göteborg and was, like everyone else, told the story about the Moldau theme. Having returned to England he wrote an article in The Observer and was totally unaware of the controversies, not to say conflicts that he started with this article.

This incidental piece of information had a curious aftermath. A gentleman attached to the Embassy of the Czechoslovak People's Republic wrote an angry letter to The Observer, denying that Smetana adopted a foreign tune for the Moldava - which, he said, "is based, like so many of the themes of this most patriotic of all Czech composers, on the folk melodies sung by the Czech people" [Kock $a$ leze dírou]. ${ }^{12}$

Quite soon the fight was not only between Sweden and Czechoslovakia but also included England (Baa-baa Black Sheep), France (Ah vous dirai-je Maman) and Israel (national anthem). Koestler then wrote to Thurston Dart for correction who answered in The Observer on July 20, 1960:

Sir, - A folk-tune is like a migrant bird; the fact that it is observed in a given place at a given time cannot be taken as proof that it originated there. A century ago Smetana may have encountered the beautiful theme of his symphony either in Göteborg or in Bohemia, but the folk-song ornithologist knows of its currency long before that.

The theme was first written down soon after 1600, in a manuscript now in a private collection in Florence. There it is described as the song "Fuggi, fuggi", composed by Giuseppino. [...]

${ }^{12}$ Arthur Koestler, “To Covet a Swallow”, in Drinkers of Infinity. Essays 1955-1967 (London: Hutchinson of London, 1968), 278. 
"Fuggi, fuggi" is one of these Neapolitan villanelles, and during the seventeenth century its flight may be traced over a great part of Europe. Sometimes known as "The Mantuan dance", it was used by Landi in his oratorio on the life of St. Alexis (Rome, 1634), by Zannetti in his violin tutor (Milan, 1645), by Playford in his harpsichord anthology (London, 1663: "Italian Rant"), in numerous books of popular sacred songs, and so on. [...]

It seems to me, therefore, that neither Sweden, Czechoslovakia, France, England nor Israel can have much right to claim Smetana's theme. To covet a folk-song is as silly and undignified as to covet a swallow, anyway, but the music historian's evidence should perhaps be heard. According to him, the tune was hatched in Italy, two centuries and more before Smetana was born; by the end of the seventeenth century it had flown over most international frontiers of its time, free and unchallenged.

Cambridge. Thurston Dart. ${ }^{13}$

It is both understandable and human that the ignorant and the amateur notice the similarities between one song and another, and therefore draw a conclusion about its origin, even if it is a false conclusion. In this respect, it is harder to understand that the misconception also has been taught at a conservatory in modern times. A colleague of mine at Göteborg University, prof. Josef Holecek, once told me that he was told about the Swedish origin of the Moldau theme when he studied at the conservatory in Prague in the beginning of the 1960s. ${ }^{14}$

\section{Smetana in Göteborg 2004}

It is obvious and certain that Smetana, with his teaching, leadership of the Harmonic Society and all his concerts together with Czapek, was the most important factor in raising the level of musical education in Göteborg, in introducing a new repertoire, and in introducing classical concerts of high artistic quality. This was something quite new.

When Smetana had gone home, Czapek continued the work of developing the musical life of Göteborg. It is in this sense that Czapek was of greater importance than Smetana in the long run. But what Smetana did was, of course, of much greater value artistically, compared with what Czapek did. It is with great sadness that I have to admit that Göteborg has not accorded Smetana the

\footnotetext{
${ }^{13}$ Another musicologist who has expressed a special interest in this song is Ferdinando Luigi Tagliavini. See his research in "Il Ballo di Mantova ovvero 'Fuggi, fuggi da questo cielo', ovvero 'Cecilia', ovvero ...” in Max Lütolf zum 60. Geburtstag. Festschrift, ed. Bernhard Hangartner and Urs Fischer (Basel: Wiese Verlag, 1994), 135-175.

${ }^{14}$ The teacher's name was Dr Vachulka.
} 
recognition he deserves. There are very few signs in the town that bear witness to Smetana's time there. And this neglect began with his final departure in 1862. For example, his music has not been performed in Göteborg to a higher degree than for example in Stockholm and in regard to the standard repertoire. ${ }^{15}$

In 1961, one hundred years after Smetana's first departure, a special room was dedicated to Smetana in the house called Börsen where Smetana held many concerts with the Harmonic Society. This small museum was installed in cooperation with the city of Prague, but it has been removed to a more secluded place in another house. For some decades there was a Smetana Society in Göteborg, but also that is no longer active. This neglect must, however, not be interpreted as a detraction of Smetana. It is only a sad example of the weak tradition in Sweden of celebrating our history and showing respect to those very special individuals to whom we forever must be grateful. And for music history in Göteborg, Smetana is one of the greatest.

\section{Smetana's Importance for the Development of Musical Life in Göteborg}

\section{Abstract}

At the time of B. Smetana's stay in Sweden (1856-1861), Göteborg was a rather small city and also the residence of several very wealthy families. The city a had good institutional basis for the development of music life. The standard for the audience as well as the level of musicians was influenced in particular by the experience with classicist musical works only sporadically influenced by new styles of the first half of the nineteenth century. With his intensive involvement in the organization of a musical life, and also as a teacher, piano virtuoso and a composer, Smetana gave Göteborg incentives that brought fruits already during his stay and were apparent even after his departure and deep into the nineteeth century. The inspiration was, however, mutual: the environment of Göteborg influenced Smetana and provided him with a wealth of rare life and artistic experience.

\footnotetext{
${ }_{15}$ The Gothenburg Symphony Orchestra - The National Symphony Orchestra - as well as The Royal Philharmonic Orchestra in Stockholm have their repertoires and programs for all their concerts computerized in databases. This makes it very easy to study how many times the orchestras have performed music by Smetana during the $20^{\text {th }}$ century and up until today.
} 


\title{
Smetanův význam pro rozvoj hudebního života v Göteborgu
}

\section{Abstrakt}

V době, kdy B. Smetana pobýval ve Švédsku (1856-1861), byl Göteborg poměrně malým městem, $v$ němž však žilo několik velmi zámožných rodin. Město disponovalo dobrou institucionální základnou pro rozvoj hudebního života, samotná úroveň posluchačů a hráčů byla utvářena především zkušenosti s tvorbou hudebního klasicismu, jen sporadicky narušované novými směry 1. poloviny 19. století. Smetana svou intenzivní činnosti na poli organizace hudebního života, v oblasti pedagogické i jako klavírní virtuóz a skladatel přinášel Göteborgu podněty, které nesly své plody již za Smetanova pobytu a byly patrné i po jeho odchodu hluboko do 20. století. Inspirativní vztah však nebyl jednostranný, prostředí Göteborgu působilo na Smetanu a poskytlo mu řadu vzácných životních i uměleckých zkušeností.

\section{Keywords}

Bedřich Smetana; Sweden; Göteborg; music life

\section{Klíčová slova}

Bedřich Smetana; Švédsko; Göteborg; hudební život

\author{
Anders Carlsson \\ University of Gothenburg \\ Box 210 \\ 40530 Göteborg, Sweden \\ anders.carlsson@hsm.gu.se
}

